\title{
Unsettling the Household: Act VI (of 1901) and the Regulation of Women Migrants in Colonial Bengal
}

\author{
SAMITA SEN
}

The advent of capitalism has traditionally been associated with a transformation of the economic and political functioning of the family. Capital is presumed to weaken, certainly to modify, gender and age hierarchies by undermining the productive role of the household. The labour market takes over the organization of work and age of consent legislations undermine parental authority in order to create the new legal subject capable of entering "free" labour contracts. The family, though it remains outside the norms of capitalism, primarily undertakes the physical and social reproduction of labour within the capitalist sphere. Such a transformation of the "family" is, however, not inevitable. In nineteenth-century India the colonial state, though avowedly committed to a free market in labour, in practice often upheld familial claims on women's labour and sexuality. As a result, gender and generational controls within the family were enhanced rather than weakened.

Capitalist development in India was premised upon a simultaneous exploitation of domestic and capitalist relations of production. Colonial capitalism found it unnecessary to strip the domestic unit of its perceived economic functions. Under colonialism, the domestic organization continued to undertake both a vital part of the production and the physical reproduction of labour outside the capitalist sphere. Thus the accommodations between the family and the labour market acquired a distinctive character. The gender division of labour did not follow clearly demarcated domains of production and reproduction. Women were neither to provide cheap labour for capital, nor were they "domesticated" to provide a reserve army of labour. The household itself remained the site for the adjustments between productive and reproductive uses of women's labour.

Indeed, the familial deployment of labour suited the colonial state more than a labour market augmented by young men and women "free" from familial control. The small family farm was crucial to colonial economic policy and the viability of small peasant agriculture depended on unremunerated family labour. Sugata Bose has argued that capitalist development itself "rested heavily on the forcing up of labour intensity within family units actually tilling the land". Consequently, from the 1860 s, two significant processes transformed the functioning of the rural household: the increase in the unpaid component of women's and. 
children's labour and the decline in its paid component. ${ }^{1}$ The division of labour in the household economy sharpened - control of capital and capital-intensive labour was concentrated in the hands of men while women undertook labour-intensive tasks of low status and poor reward. ${ }^{2}$

The family arrangements the colonizers inherited could not just be taken over, they had to be adapted to these new needs. To that end, new legal measures were introduced to buttress family authority. Colonial laws repeatedly interceded to elevate the powers of the male head of the family through regulation of inheritance and marriage laws. A range of legal and administrative initiatives were aimed at enhancing familial control over women's bodies - their labour and their sexuality. ${ }^{3}$

The convergence between the reinforcement of gender hierarchies within families and the sharpening gender division of labour in the household was reflected in the pattern of migration. In long-distance migration to cities and plantations adult men predominated. This was especially the case in "free" migration to the cities. The rural household, especially women and children left behind by migrants, remained responsible for reproducing, partially or wholly, the urban workforce. While industrial capital benefited from employing the labour thus reproduced, it made no direct contribution by way of wages or as revenue. When men went to the city to earn cash wages, the women and children who stayed in the village had to eke out a living from the family farm, wage labour and unpaid "subsistence" activities. In areas like Saran in north Bihar, which was a major catchment area for Calcutta's labour market, women's visibility in the workforce rose sharply. The worker

\footnotetext{
' Sugata Bose, Peasant Labour and Colonial Capital. Rural Bengal Since 1770. New Cambridge History of India, III-2 (Cambridge, 1993), pp. 66-111.

${ }^{2}$ Nirmala Banerjec, "Working Women in Colonial Bengal: Modernization and Marginalization", in Kumkum Sangari and Sudesh Vaid (eds), Recasting Women: Essays in Colonial History (New Delhi, 1989), pp. 283-288 and "Women's Work and Discrimination", in Nirmala Banerjee and Devaki Jain (eds), Tyranny of the Household: Investigative Essays on Women's Work (New Delhi, 1985), pp. 110-121. Mukul Mukherjee, "Impact of Modernisation of Women's Occupations: A Case Study of Rice Husking Industry in Bengal", in J. Krishnamurty (ed.), Women in Colonial India: Essays on Survival, Work and the State (New Delhi, 1989) and idem, "Mechanisation in Food Processing and Women's Employment", in Mira Savara and Divya Pandey (eds), Between the Farm and the Thali: Women and Food Processing (Bombay, 1990). For an investigation into progressive gender inequities in distribution of household resources see Amartya Sen, "Family and Food: Sex Bias in Poverty", in idem, Resources, Values and Development (Oxford, 1984).

${ }^{3}$ M.R. Anderson, "Work Construed: Ideological Origins of Labour Law in British India to 1918", in Peter Robb (ed.), Dalit Movement and the Meaning of Labour in India (New Delhi, 1993), pp. 87-120; Bernard S. Cohn, "Law and Colonial State in India", in J. Starr and J.F. Collier (eds), History and Power in the Study of Law (Ithaca, 1989).

- L.S.S. O'Malley, Bihar \& Orissa District Gazetteer, Saran (Patna, 1930), p. 86.
} 
in the city could return to the village when he was ill or unemployed and when he eventually retired.s

Such arrangements suited the textile industries, jute and cotton, because they gave their male labour force the two characteristics most required - cheapness and flexibility. ${ }^{6}$ But this is not to say that the emerging capitalist enterprises made no demands on women's labour. In eastern India, by the end of the nineteenth century, there were three clusters of large-scale capitalist enterprise. The jute industry grew in and around Calcutta: women workers were not supposed to have any gender-specific skill to offer this industry; they rarely exceeded 14-16 per cent of this workforce. Coal mining prospered in the Raniganj-Jharia belt and the tea plantations were making rapid headway in north Bengal and Assam. The mines adapted "family" labour, employing in the 1910s and 1920s about 27-28 per cent women and children in their workforce. The tea plantations, concerned with a settled and stable workforce and preferring cheap labour for plucking leaves, employed as many or more women as men. In the late nineteenth and early twentieth centuries the tea plantations, especially those in Assam, and the colonial plantations overseas were devising ways and means of recruiting more women.

The possibilities of women's long-term and long-distance migration upset the desired gender equations within the family and the accommodations between the productive and reproductive uses of women's labour. Attempts at large-scale recruitment of women for plantations raised a storm of debate, and all the parties involved in the controversy sought the Government of India's intercession. The planters were supported by the Imperial Government in demanding better facilities for recruiting women. Local elites supported by local state officials demanded legal restrictions on recruiters and on women's freedom to enter labour contracts. This essay will focus on one legislative intervention of the government: the Assam Labour and Emigration Act (Act VI of 1901). The government clearly vacillated between the conflicting demands made on it. The Act seemed to give by legislation power to the head of the household to restrain women's migration and recruitment. But by administrative fiat and through the racial alliances

S Samita Sen, "Women Workers in the Bengal Jute Industry, 1890-1940: Migration, Motherhood and Militancy" (Ph.D., Cambridge University, 1992). For a discussion on the role of remittances and the links between the jute working class and the rural economy, see Gail Omvedt, "Migration in Colonial India: the Articulation of Feudalism and Colonialism by the Colonial State", Joumal of Peasant Studies, VII, 2 (1980).

- For the Bombay cotton textile industry see R.S. Chandavarkar, The Origins of Industrial Capitalism in India: Business Strategies and the Working Classes in Bombay, 1900-1940 (Cambridge, 1994). For the Calcutta jute industry, see Sen, "Women Workers in the Bengal Jute Industry" and $O$. Goswami, Industry, Trade and Peasant Society: The Jute Economy of Easterm India, 1900-1947 (New Delhi, 1991).

'Banerjee, "Working Women in Colonial Bengal". 
of administrators and agents, the effects of these laws were often nullified.

\section{The recruitment of women for tea gardens and overseas plantations}

The migration decisions of the peasant household were influenced by the increasingly critical role women played in the rural subsistence sector. A clearly gendered pattern of migration emerged in the nineteenth century. Individual and group migration of women predominated in seasonal inter-district movement of labour. ${ }^{8}$ Such migrations were part of the household's labour deployment strategy and did not threaten familial control. Long-distance and long-term migration, however, posed a conflict with women's subsistence and reproductive activities. Women and children's labour was more profitably - for the urban employer and the peasant household - retained in the village. When rural resources were exhausted, whole families undertook permanent migration. However, women sometimes did migrate alone - without their families when they were denied access to household resources. Widows, childless women, deserted wives, wives in unhappy marriages and women entering extra-marital sexual relationships often found migration their only option. Some went to the cities, some to the colonies and some to the Assam plantations. Most such migrants repudiated the "rural" connection that women migrating in families and single male migrants were able to retain.9

In the early years, and until the 1920 s, urban and industrial employers hired widows and deserted wives, though their proportion was always low, declining over time..$^{10}$ As the industries switched to employing more workers from Bihar and Uttar Pradesh (UP), women's share in the workforce declined more sharply. The numbers of these single female migrants who came to the cities were, compared to the men, very small. As far as the urban employers were concerned, there was a large available supply of male labour, and they thus made no serious attempt to tie labour down by contract. Their proximity to Calcutta ensured a ready supply of workers at the mill gates. They did not have to contribute substantially to the costs of labour migration. It was more advantageous to have a proportion of "floating" labour that could be hired and fired according to the requirements of the international market. In contrast, planters, both in Assam and the overseas colonies, depended heavily

- O'Malley, Bihar \& Orissa District Gazetteer, Saran, p. 30.

- Report of Dr Dagmar Curjel on the conditions of Employment of Women Before and After Childbirth, 1923, unpublished, West Bengal State Archives (hereafter WBSA), Calcutta. Commerce Department Commerce Branch, April 1923, B77 (hereafter Curjel Report).

10 Indian Factory Commission, 1891. The proportion of women in the jute labour force began to decline from the 1920s. Sen, "Women Workers in the Bengal Jute Industry". 
on tying down workers. Their problem was to ensure a steady supply of labour and to do this they had to invest heavily in recruitment which was covered by penal contracts. ${ }^{.1}$

The export of Indian workmen under indenture to colonies in Australia and the Caribbean began in the 1830s when the abolition of slavery created a demand for cheap and controllable labour. Initially, women constituted a minuscule proportion of such workers. ${ }^{12}$ The planters in the receiving colonies were not particularly interested in women: They wanted direct labour and men were thought more productive and capable of heavier workloads. Besides, they depended on migration itself to replace workers. To ensure a self-reproducing workforce they would have to incur some additional costs. They would have to encourage family migration which meant financing the migration and maintenance of some dependants - particularly wives and children. Even if wives were inducted as workers, there would be inevitable "financial disabilities due to the financial risks of child-bearing and rearing". ${ }^{13}$ However, the representations of the receiving colonies proved serious especially since they gained the support of the Home Government. Colonial governments complained that large numbers of "single" Indian workmen caused high rates of crime and social dislocation. In the 1860s the Government of India attempted to alleviate the situation by fixing a minimum of $\mathbf{4 0}$ women to every 100 men (except in Mauritius which allowed 33 women for every 100 men) per shipment. ${ }^{14}$ London continued to push for a stable and settled community of Indian workmen and women in the colonies. In 1875 Lord Salisbury preferred settlement and colonization rather than temporary labour engagements. He argued for "the emigration of a sufficient proportion of women of an honest and decent class". ${ }^{15}$

In the late nineteenth century even the Caribbean planters began to exhibit more interest in women immigrants. The pulls between short-term preference for adult male immigrants and the long-term advantages of

"The Workmen's Breach of Contract Act (Act XIII of 1859) was strengthened and reinforced by Act VII of 1873 and Act I of 1882 .

12 In the first batch there were some 6,000 men and 100 women. For more details see Hugh Tinker, A New System of Slavery: The Export of Indian Labour Overseas 18301920 (Oxford, 1974).

s Rhoda Reddock, "Freedom Denied. Indian Women and Indentureship in Trinidad and Tobago, 1845-1917", Economic and Political Weekly, XX, 43 (1985); Jo Beall, "Women under Indenture in Colonial Natal, 1860-1911", in C. Peach and S. Yettovec (eds), South Asians Overseas. Migration and Ethnicity (Cambridge, 1990).

14 These ratios changed over time and for different colonies several times in the nineteenth century: Bridget Brereton. "The Experience of Indentureship 1854-1917", in John La Guerre (ed.), Calcutta to Caroni (Longmans Caribbean, 1974). Also see Brian L. Moore, "Mating Patterns and Gender Relations Among Indians in Nineteenth-Century Guyana", Guyana Historical Joumal, III (1991), pp. 1-12.

is Lord Salisbury to the Govermor-General of India in Council, 24 March 1875; Report of the Indian Jute Manufacturers' Association (Calcutta, 1899). 
a self-reproducing cheap and stable workforce became evident when planters feared an end to labour emigration from India. They began to pay a premium for women recruits. ${ }^{16}$ It was when the sugar crisis in the late nineteenth century began to bite that the planters began to be seriously interested in "family". Lower wages and shorter indentures failed to solve their problems. They began to encourage cane farming in small family holdings. The women did most of the regular field work, producing cane and undertaking subsistence food production. Men worked in the estates and provided additional labour on the farms during harvests and in their spare time. This allowed a further depression of wages, a ready reserve of labour and an alternative source of cane. ${ }^{17}$

The tea planters of Assam had from the beginning encouraged family migration. ${ }^{18}$ Their main catchment area had thus become the tribal belts of Bengal, Bihar and Orissa where periodic scarcities prised out whole families towards Assam and the Sunderbans. ${ }^{19}$ The tea plantations were located in uninhabited, inhospitable and inaccessible areas. The planters could not, like the jute mills, draw on migrants attracted to Calcutta's expanding labour market. They had to invest men and money to organize recruitment and ensure a sufficient supply of labour. But their recruitment was not organized under agents as in the case of the overseas plantations. ${ }^{20}$ The Commercial Association was particularly worried by the unpopularity of Assam among migrants, especially women, who seemed to prefer to go to the colonies or remain in Calcutta. In the 1860 s the emigration to tea districts was in fact less than 10 per cent of the total overseas emigration. The tea lobby repeatedly sought to highlight "Indian" commercial interests against the larger "imperial" interests that Salisbury had so forcefully represented. ${ }^{21}$

The tea planters were in fact interested in captive labour. More importantly, in the longer term they were looking towards a stable and self-reproducing labour force. Women migrants as potential reproducers of labour were essential to their calculations. They were thus the first industry to offer rudimentary maternity leave and benefits. ${ }^{22}$ Besides,

${ }^{16}$ Reddock, "Freedom Denied".

$"$ Ibid. Also see Tinker, A New System of Slavery.

13 Radhakamal Mukherjee. The Indian Working Class (Bombay, 1945), pp. 15-20.

19 For a well-documented account of this migration see Haraprasad Chattopadhyay, Internal Migration in India. A Case Study of Bengal (Calcutta, 1987). The other major stream of migration to Assam was from East Bengal. Peasant families resettled in Assam to undertake the reclamation and cultivation of waste land. The low wages in the tea plantations could not attract these peasant migrants or the local peasantry. There was also a concentration of tea plantations in North Bengal. Ostensibly these were supplied by "free" migration as opposed to the indentured migration that obtained in Assam.

>0 The "free contracting" system came to be regulated from 1863 by the Inland Emigration Act (Bengal Act III of 1863).

31 WBSA, General Emigration, January 1862, A6.

z Curjel Report. 
and more importantly, women's labour was valued for subsistence farming and for the labour-intensive task of plucking leaves. This latter task could not be mechanized easily and without enormous outlay of investment. The cheap and "nimble" fingers of women and children were an added bonus for planters which they were loath to relinquish. When "family" migration failed to meet their requirements, "unattached" men and women were encouraged to "settle" in families in the plantations." They could not wait for the "free" operation of the labour market to bring forth women. They extended their own coercive apparatus developed with the collusion of the colonial state specially to target women's recruitment.

In the late nineteenth and early twentieth centuries thus there were increased efforts to recruit women for overseas and Assam plantations. Agents for colonial recruitment, tea garden sardars and arkathis complained of the scarcity of women willing to migrate under contract. ${ }^{24}$ In the case of the colonial recruiters, the Emigration Branch of the Government of Bengal opened a special file entitled "Short Shipment of Females" to accommodate the numerous applications from agents for permission to ship labour even when the proportion of women did not meet the statutory requirements. ${ }^{25}$ Enquiries in the North-Western Provinces and Oudh and in Bihar into the system of emigration from British India to the colonies revealed that, "admitting that the proportion of 40 women to 100 men was by no means excessive [ $\ldots$ ] this proportion could not be readily obtained except at the expense of serious abuses". ${ }^{26}$

Colonial recruiters, like plantation recruiters, met the statutory requirements by coercive methods. ${ }^{27}$ Unable to find women recruits in

23 WBSA, General Emigration, October 1889, A139-40.

24 The colonies usually appointed agents in Calcutta and Madras who contracted out recruitment to sub-agents working on commission. The tea planters employed licensed labour contractors who were called arkathis and Garden Sardars, reliable workers who were paid fees and costs to bring more workers directly to the gardens. The arkathis were professional recruiters, while the latter were supposed to recruit only from local and family networks. Planters sometimes preferred sardari recruitment because it made labour supervision more effective. The government argued in favour of sardari recruitment on the grounds that it eliminated fraud. From 1919 only the Garden Sardari system was allowed. There were two types of sardars - those who worked independently and those who worked under the control of Licensed Local Agents appointed by the Tea District Labour Supply Association, other recognized associations and individual employers. The Act VI of 1901 granted these latter some special concessions under Section 91: Annual Report on Inland. Emigration under the Assam Labour and Emigration Act VI of 1916 (Calcutta, 1916).

2s Report on the Emigration from the Port of Calcutta to British and Foreign Colonies (Calcutta, 1909-1918).

${ }_{26}$ Bihar State Archives (hereafter BSA), General Emigration, May 1885, Nos 6-8.

I) E. Van Cutsem, Emigration Agent for Surinam to the Protector of Emigrants, Calcutta, BSA, General Emigration, May 1885, Nos 6-8. 
the normal course, they resorted to kidnapping. Various charges of unscrupulous and coercive recruitment were brought against emigration agents and tea planters. In the last three decades of the nineteenth century attention focused on the "kidnapping" of women. A statistical estimate of the extent of fraud and coercion practised by recruiters is difficult to cull from the available evidence. However, there is little doubt that, increasingly, from the end of the nineteenth century, the "kidnapping" of young women figured as an officially recognized problem. The drastic methods adopted by recruiters provoked a characteristic debate between those who emphasized women's "familial" role and others who upheld her "right" to sell her labour.

The emigration agents offered a simple solution. The agent for Surinam, Van Cutsem, argued "that practically the only abuse in connection with emigration occurs in the recruitment of women" and that the "class of women being frequently sent to the colonies [ . . ] are worse than useless". ${ }^{28}$ The government, the agents believed, should relax the quota system. The Government of India was, however, under considerable pressure from London and the colonies to provide more women emigrants and a "better class of women". It was felt that social disorder was exacerbated by a large influx of "prostitutes" and "lax women". Agents pleaded that such were the only women available for migration. Salisbury was persuading the Government of India to protect the "habits of morality and decency of the Indian population of some of the Colonies" which was endangered "by the scarcity of honest women and want of family life" by promoting emigration of women "free from social prejudices" and "of agricultural and labouring classes".29

The collective weight of these representations prompted the government to attempt an investigation into the ways of facilitating more women's migration. Major Pitcher and Mr Grierson were appointed by the government to assist in recruiting women. They gave some specific recommendations: that the surplus women in one shipment should count towards the supply of the next; that separate accommodation and medical examination should be provided under the supervision of female personnel; and that licensed women recruiters should be employed for recruitment of women. But their two main recommendations were the most controversial. Against the tenor of official opinion that allegations of "kidnapping" should be investigated thoroughly, they argued

that the system of enquiry through the police after missing female relatives should be stopped: the single women should be either detained at the depot for week or ten days, or the enquiry should be made through the Civil Executive Agency. ${ }^{30}$

23 BSA, General Emigration, March 1885.

29 Lord Salisbury to the Governor-General of India in Council, 24 March 1875; Report of the Indian Juse Manufacturers' Association (Calcutta, 1899).

30 BSA, General Emigration, May 1885, Nos 6-8. 
This was in line with their strong contention that the only way to facilitate the emigration of "respectable" women was to "generally concede women more liberty of independent action than is allowed them at present". They were thus in favour of repudiating the right of fathers and husbands to influence individual women's migration decisions. ${ }^{31}$

\section{The patriarchal response - "kidnapping" or "voluntary" flight?}

In the 1840 s the Government of India had been relatively unperturbed by the criticism that male immigration to the colonies left families stranded. ${ }^{32}$ It had taken the combined representations of the Home Government and officials in the receiving colonies for the government to look into the question - not because the families left behind were vulnerable but because of the social "instability" in the receiving colonies and the planters' increased interest in women's productive and reproductive labour. Their solution too did not take account of the families of male migrants left behind in India. The quota system they introduced was more directed towards redressing the sex imbalance in the colonies. It allowed, and indeed prompted, a higher incidence of fraudulent recruitment of "unattached" women to make up the quotas when families proved difficult to recruit. The solution itself raised other intractable problems. The government found it impossible to take the same insouciant approach to the question of families left behind by women who migrated alone as they had in the case of families "deserted" by adult male emigrants.

In recommending greater autonomy to women migrants and dismissing the claims of the family to control women's migration decisions, Grierson and Pitcher seemed to have represented a minority opinion in official circles. Many local officers in labour catchment districts agreed that women's migration outside the family context was deviant. They believed that such migration, voluntary or involuntary, threatened familial control over women's labour and sexuality. They had to deal with increasing numbers of cases of missing wives and daughters. Many district level functionaries began to call for stringent legislative restraints on recruiters to protect the interests of fathers and husbands. A magistrate wrote from Chhotanagpur: "To protect husbands from the wiles of the coolie recruiter, there should be some $[\ldots]$ order $[\ldots]$ regarding the registration of married women." 33 The arguments advanced by officials

"Ibid.

32 In the 1840s; the Protector questioned 48 returning emigrants. Apparently, the men "reposed perfect confidence" that their wives and children were cared for in their absence. McFarlen argued that it was not uncommon for men to go away as sepoys, bearers or to Calcutta to do odd jobs: D. McFarlen, Memoranda of 48 Examinations of Mauritius Labourers returned to Bengal in the "Graham" (Calcutta, 1841).

33 WBSA, Judicial Police, August 1873, A95-98. 
to restrict the emigration of women clearly spelt out the two most problematic aspects of unregulated recruitment. The possibility of emigration, it was often asserted, widened women's sexual choices, thereby undermining their control and containment within marriage. In such arguments, the line between illegitimate and exploitative sexual relations were often blurred: exploitation was seen to be the invariable and inevitable consequence of illegitimate sexual liaisons. The other line of argument concentrated on the domestic role of women. The concerned elite Indian men and British officials drew moving and poignant portraits of the deserted husband, the uncared home and the abandoned child. In both narratives, the key was marriage and the deployment of women's labour and sexuality which were in danger of disruption by women's emigration. One magistrate complained that the kidnapping of young women was causing

great hardship and distress in many families $[\ldots]$ the frequent practice of cooly recruiters inveigling away married women from their husbands and children, which latter are in some cases of such tender age as to be exposed to great risk of dying from being deprived of their mother's milk and care. ${ }^{34}$

The coercive recruitment tactics of plantations and emigration agents had hardened patriarchal opposition to women's migration. Objections to women's recruitment for dispatch to Assam and the colonies poured forth from various quarters. The critical questions thrown up in the debates that followed were: whether women's migration was actually "voluntary" and, if so, whether women were to be allowed such "voluntary consent". There were those who believed that women would not and could not voluntarily abandon home and family to migrate to distant tea gardens or overseas colonies where they had to work long hours in appalling conditions. Moreover, in the plantations, the women became victims of sexual harassment and molestation. In these views, poverty, violence and sexual anarchy were inextricably bound to plantation life. The many objections to women's "voluntary" migration turned on four arguments: that recruiters often forcibly "kidnapped" women for Assam and the colonies; that even when the women appeared to have consented to migrate, their recruitment constituted "kidnapping" because they were deceived about the conditions of life and employment; that these conditions were so degrading that no women would, knowingly, opt for migration to Assam or the colonies; and that, moreover, even when no fraud was perpetrated, women, especially married women, were not entitled to enter into contract without the consent of their guardians. The last two arguments often came together when presented by British officials and elite Bengalis. Emigration to Assam or the colonies was seen to offer women an opportunity for economic independence and a 
means of exercising their sexual choices which undermined the institution of marriage and the maintenance of familial control.

In the 1870s, a district judge heard a case against Sheikh Panchoo, a recruiter, who was charged with the kidnapping of Nobin Mochi's wife. The woman in question was 20-22 years old. She testified that she had left Nobin "voluntarily". Moreover, it could not be proved that she was married to Nobin "even by nika marriage". The judge was unable to convict but he was sympathetic to Nobin. Such recruitments, he felt, were "against law and morality". Jaggo Mahto had been charged with the abduction of 11-year-old Geerdharee Bhooyan. Nothing could be proved, but the magistrate felt that since the result of emigration was often that

the women, thus leaving their husbands, go into the keeping of other men, and that the act of enlistment though not illegal at the time becomes tantamount to inducing a married woman to leave her husband for an immoral purpose which the recruiter knows full well will be the result and he can recruit such a woman with perfect impunity. ${ }^{35}$

The magistrate, therefore, recommended that "a clause should [ . . ] be inserted in the recruiter's licenses prohibiting their enlisting married women without the consent of their husbands". ${ }^{36}$

The enticement of married women "for immoral purposes" was already a cognizable offence under the Indian Penal Code. It was not clear, however, whether such a clause could be used against recruiters. A district magistrate of Chhotnagpur, which was one of the main recruiting grounds for tea labour, argued that the spirit of the law would be violated if a clause designed to deal with the sale of women into prostitution was stretched to cover labour contracts. But to him, as to many others, there was little difference between the practice of prostitution and the non-marital or extra-marital sexual relationships into which women entered when they reached the tea gardens or the colonies. He argued that since Section 366 of the IPC could not be applied to these cases, other similar legislative or administrative measures had to be taken to prevent "enticement" of married women. ${ }^{37}$

Charges of enticement were still easier to handle than "abduction" and "kidnapping". A charge of enticement could on occasion be made to stick even if the women's willingness to be thus "enticed" remained questionable. Many cases of "kidnapping" and "abduction" were, however, brought to nought because women were willing to declare their consent before the magistrate. By definition, "abduction" and "kidnapping", except when they involved minors, assumed forcible apprehension against the will of the "victim". Thus when a sardar was charged with

3s Ibid.

36 Ibid.

"Ibid. 
the kidnapping of three young women, the registering officer recorded that though there had "[ . . . ] undoubtedly been great deceit practised by the accused [...] the offence of kidnapping had not been established". ${ }^{38}$ Many cases came to hinge on proof of the nature and extent of deceit practised by recruiters. It was generally believed that

presents of ornaments and clothes and the glowing accounts the recruiters give of the ease and luxury the women will enjoy in the tea districts which contrasted by them with the hard fare and work to be done at home often succeeds in inducing them to leave their families $[\ldots]^{39}$

Such official representations found echoes in the writings of elite Bengalis. In the 1870s and 1880s Dwarkanath Ganguly and Ramkumar Vidyaratna wrote in the Sanjibani harrowing accounts of sexual harassment in the Assam gardens. ${ }^{40}$ The violation of "Indian" coolie women by European men provided a potent symbol of colonial exploitation and oppression." 1

Ganguly believed, like some British officers, that "recruitment" was "tantamount to inducing a married woman to leave her husband for an immoral purpose". 2 Recruiters, goaded by plantation managers, practised great deception to recruit women who were susceptible to the attraction of wages and a good life. In a fictionalized account of his experiences, Kulikahini, Ramkumar Vidyaratna described in detail the recruitment of a peasant woman, Adarmani. The recruiters seduced her by holding out attractions of rich clothes, ornaments and comforts which provided a stark contrast with her misery and drudgery in the village home. The author made it clear that in succumbing to these wiles Adarmani was not only revoking male authority but was inviting its terrible consequences. ${ }^{43}$

\section{The Act of 1901 - constraints on women's recruitment}

In the closing decades of the nineteenth century, then, there were various interests competing for labour in north India. Each staked their claim to special patronage from the Government of India. The Home Government condemned the Indian Government's indifference to overseas labour migration and accused them of not paying adequate attention

\section{Ibid.}

39 Ibid.

* Dwarkanath Ganguly, Slavery in British Dominion, ed. Srikumar Kunda, comp. K.L. Chattopadhayay (Calcutta, 1972).

"Samita Sen, "Honour and Resistance: Gender, Community and Class in Bengal, 192040", in Sekhar Bandopadhyay et al. (eds), Bengal: Communities, Development and States (New Delhi, 1994).

2T The Bengalee, XXVIII, 4, 22 January 1887, reproduced in Ganguly, Slavery in British Dominion.

3. Ramkumar Vidyaratna, Kulikahini [Sketches from Cooly Life] (Calcutta, 1888), pp. 6-7. 
to larger imperial interests. The tea planters sought to represent "Indian" capitalist interests and based their appeal for privileges in the labour market on the grounds that India could corner a part of the tea market dominated by the Chinese. The big landlords had been objecting to the depredation of their labour since almost the middle of the nineteenth century. ${ }^{44}$ Along with such arguments the focus on the "abuses" of labour recruitment sharpened. The British official and elite Bengali outrage against the challenge to patriarchal family authority added further fuel to these debates.

The colonial state found itself committed to the protection of these conflicting interests. Despite the government's earlier disinclination for further labour legislation, in 1901 the Assam Labour and Emigration Act (Act VI of 1901) was passed. Ostensibly the Act was meant to reduce the role of arkathis and encourage sardari recruitment on the grounds that sardars recruited from locales where they were known. ${ }^{45}$ Meanwhile, the various pressures to take special measures to avoid abuses in women's recruitment had to be taken into consideration. Even the Chief Commissioner of Assam, the province attracting women tea workers, drew attention to this problem.

It is [ . . the case] of the female waif or stray, the woman who has been deserted by her husband, the woman who has left her home after a quarrel, the first wife who has been superseded by a second, the wife of a Coolin Brahmin, and such like. Such women are often ready to go anywhere with anybody and to do anything, and they seem not unfrequently to fall the victims to the professional arkati or recruiter. They have $[\ldots]$ to be deceived by some false representation, and they are probably told that a home will be provided for them either as domestic servant or in a less honourable capacity, or perhaps the person who enlists one of them tells her that he will himself marry her or keep her as his mistress [...] It is only when she is put on board the steamer, and her deceiver leaves her that she is brought to understand what is before her,. and the deception comes to light. ${ }^{\text {to }}$

The Superintendent of Police, F.H. Tucker, inundated with complaints, also advocated extensive examination of recruiting. The "big abduction cases" of 1885-1886 were a further goad. ${ }^{47}$ The government found itself more than ever caught between the interests of British capital and the displeasure of indigenous elites, missionaries and some of their own officials. On the one hand, the Home Government and the Indian Tea Association wanted less regulation of women's recruitment and the curtailment of criminal enquiries after missing women by fathers and husbands. Grierson and Pitcher had recommended reforms along these

\footnotetext{
4s WBSA, General Emigration, January 1862, A6.

is Ibid., July 190-4, A6-15.

46 Ibid., January 1890, A139-40.

17 Ibid., A42-4.
} 
lines. On the other hand, the state had to address the questions raised by the collective weight of cases of kidnapping.

In the end the government's response was to run directly counter to Grierson's recommendations. Section 9 of the Act of 1901 empowered registering officers to refuse registration to and detain women who were emigrating without the consent of their "lawful guardian", husband or father or brother as the case may be. Several categories of recruits were defined who were to be discharged from the depots and not despatched to the colonies: those refusing to emigrate; the Brahmins, Vaishyas, etc., who had not worked as coolies; those whose relations asked for their release; those recruited in one district but registered in another; minors; and women whose husbands were living. These last four provisions, devised as a concession to concerns about the familial control of women, were meant to check the "kidnapping", "abduction" and "enticement" of women.

These provisions were meant to quieten fears that widening women's migration options would threaten familial control over their labour and sexuality. The local elites and officials had thus successfully invoked state aid to stake out family control. Many district officials argued that only legislation would protect the interests of husbands whose wives were "kidnapped" by recruiters. Not only did husbands and children need protection from the recruiter but women who wished to escape them had to be prevented or punished. The provisions of the Act of 1901 were justified on the grounds that

the deportation of wives against the will of their husbands should be absolutely prohibited, and [...] Magistrates would be absolutely justified in refusing to pass any woman so situated [ ...] A married woman may be said to have entered into a contract with her husband which precludes her from engaging in services to another party for a term of years without his consent. ${ }^{48}$

The Lieutenant-Governor agreed that it should be a penal offence for a wife to be recruited without permission of husband or guardian.9 From the mid-nineteenth century, the British sought by statutory intervention to restrain women's mobility, their ability to escape unhappy marriages or resist familial authority. An increasingly orthodox interpretation of marriage became the key to reinforcing male authority in the family, both as a guarantee of political stability and as a means of curbing women's resistance to coercive extraction of labour. This disability in particular affected low-caste women adversely since their marriages often resembled forced labour arrangements and the prevalence of divorce was the only avenue of escape open to some of them.

A provision for restitution of conjugal rights, which the LieutenantGovernor had rejected in 1800 , was introduced by judicial decision in

wBSA, Judicial Police, August 1873, A95-8.

Ibid. 
1867 and later incorporated in the Code of Civil Procedure (1882) Section 260 and 1908 CCP (Order 21 under Rule 32). Men were thus permitted the use of courts to restrain wives who wished to migrate to Assam, the colonies, to cities and towns or even to live with other men. The control of women's work within the family was thus enhanced.

It was curious, however, that the Lieutenant-Governor subscribed to the notion that a woman by marriage "entered into a contract". The British Indian courts had held that Hindu marriage was, in fact, a "sacrament". "Hindu" marriages were thus set apart from Muslim and Christian marriages. The Madras High Court therefore ruled that even separation from a husband did not constitute grounds for divorce and/ or remarriage by a Hindu woman as long as her husband lived. Hindu men did not require divorce since polygyny was given full legal status. Polyandry was, however, completely rejected. In addition, "customary" divorces among low-caste women were criminalized and their second marriages were rendered invalid. The husbands by such marriages became vulnerable to charges of "abduction" and "seduction" and the women could be indicted for bigamy. All these were criminal offences. Despite the widespread practice of nika among lower castes in Bengal and Bihar, colonial officials held that it was a Muslim custom and would not apply to Hindu women..$^{50}$ For Muslim women too the right of initiating divorces was being eroded, though the dissolution of a marriage at the man's instance was widely accepted. Thus while the characterization of all marriages as contractual went against the tenor of the colonial legal discourse in the late nineteenth century, in this particular instance such an interpretation was in tune with the general movement towards a rigidification of gender hierarchy.

The Act of 1901 gave men - fathers and husbands - an additional means to restrain runaway women. It was often invoked to stop women who sought to escape, either alone or with lovers. It was recognized that in every district of the province there were cases of "kidnapping" related to girls being "carried away by their paramours", or taken with the object of marrying them without consent of the family. The extensive use of the term "kidnapping" not only emphasized the legal status of women as minors, but the term had to be given a new legal meaning

\footnotetext{
so The term nika was derived from an Arabic word meaning marriage. In nineteenthcentury Bengal, many Muslims called the first marriage shadi (meaning delight) and ritually celebrated. According to colonial officials, the second marriage was called nika and, even among Muslims, influenced by Hindu notions of second marriage being disgraceful, performed with less ceremony. Among the lower castes, divorcees and widows were allowed to remarry. Many of them (including some Vaishnava sects) seemed to have termed their second marriages nika, though they were also termed sanga or sangat or even sagai. Some colonial officials argued that such a second marriage was concubinage in the case of a divorced woman, but because of its wide acceptance it should not be made a penal offence: WBSA, General Miscellaneous, April 1874, B1-15.
} 
to account for women who consented to their "kidnapping". Since legal restraints on women's mobility construed voluntary flight as "kidnapping", the "offence" became impossible to establish. ${ }^{51}$

The attempt to establish kidnapping by arguing that the women's "consent" was invalid when obtained by deceit was obviously fraught. Doubtless deceit and fraud were the stock-in-trade of recruiting agents. They held out (usually false) prospects of high wages, good working conditions and even marriage. It is also certain that some women did choose to migrate to the gardens of Assam or to distant colonies. A recruit, Jainaff Bibi, rescued from a depot in Calcutta testified that, though she had been deceived, she had accompanied the recruiter willingly.

I fell in love with a man named Jame. He was perhaps one of the cooly recruiters. He said that he would get me admitted into a cooly depot and then after securing my discharge by paying the usual fee of Rs. 30 on my arrival in Calcutta, would marry me under the nika form, so that my own people might not claim me. 52

The pressure to recruit only adult women of "respectable antecedents" exacerbated the issue. The legal formalizing of familial rights over women's mobility made it relatively easier for women who were marginalized in the family or deprived of familial resources to migrate than married women, whose recruitment was more likely to be challenged. Recruiters were forced to seek out "women who were either of bad repute, or were involved in domestic troubles" to make up the required proportion. ${ }^{33}$ Young girls and widows often fled from home because of ill-treatment or domestic strife and fell victim to unscrupulous procurers and labour recruiters. Sometimes married women sought escape from the harassment of a husband or in-laws, or a quarrel might trigger off flight. Such women had little access to resources outside the family and emigration might have seemed a viable option providing some economic independence. Munni was a Rajput from UP. She was 18 years old and married to a 9 year old: "I was therefore never on good terms with the members of my father-in-law's family [ . . M]y mother-in-law gave me much trouble and never sent me to my father's house."st She had run away from home and had been decoyed by a recruiter. Rampyari Halwayin had fallen on hard times because "[ ... ] about a year ago my husband has gone away, I do not know where" and in her search

s1 WBSA, Judicial Police, August 1873, A95-98.

5 Translated from Bharatmitra, 28, 29 and 31 October and 1, 2, 4 and 5 November 1913. WBSA, Finance Emigration, November 1915, B5-7.

s3 Report of the Inter-Departmental Conference held in London in 1917 to Consider Pro. posals for a New Assisted System of Emigration from India to British Guiana, Trinidad and Fiji, WBSA, Commerce Emigration, July 1918, A1-16.

st Ibid. 
for work she had found her way to the depot. ${ }^{55}$ The Act of 1901 did little to reduce such recruitments. In 1913 five cases were cited against recruiters. One widowed and orphaned girl who quarrelled with her aunt, another 25-year-old woman who fell out with her mother-in-law, another who left with her son because her husband took another wife with whom she did not get along. In all these cases, the women were promised employment in Calcutta and then decoyed to a tea garden. ${ }^{56}$ While some of these women were actually taken to plantations or to the colonies, others who managed to escape or were released could not return to their village home. They found their way to the tenements of Calcutta and the jute mill towns. ${ }^{57}$

The Act had sought to resolve the controversy over the legal definition of "voluntary consent" by altogether denying women the capacity to consent and by deferring that right to the husband/guardian. This raised other complicated questions: the issue of guardianship in case of widows and deserted wives and, more important, widely practised customs of divorce and remarriage.

In the end, legal confusions about "consent" helped towards confounding the provisions of the Act. The magistrates were often unable to prevent even enticements and kidnappings. In 1901 so many women recruits presented to the registering officer were suspect that the Commissioner of the Chhotanagpur division felt that the practice of detaining the women in the thana was undesirable and inadequate, especially since some women were delivered of children while in custody. ${ }^{58}$ In the Central Provinces, in 1904-1905, all prosecutions regarding illegal recruitment related to the enticement or kidnapping of young women..$^{59}$ In 1913, out of 49 persons who were rejected for registration at Naihati, 13 were young women who could not prove that they had the consent of their lawful guardian. ${ }^{60}$ "During the present season, 120 coolies were kidnapped many of them young, married women", said an article in Capital in February 1911.61 The figures in government reports are too fragmentary to allow us to estimate whether such cases actually decreased after the Act of 1901. Without doubt, however, the frequency of incidents of "kidnapping" and "abduction" continued to trouble district authorities in recruitment districts. Their reports for 1911 and 1912 give some

ss Statement, Alipore Court, 11 May 1911. WBSA, Finance Emigration, November 1915, B5-7.

so Ibid., February 1913.

"Sen, "Women Workers in the Bengal Jute Industry".

ss Special arrangements had to be made with the local Lady Dufferin Fund Committee. WBSA, General Emigration, December 1901, A23-30.

${ }^{39}$ Report on the Working of the Inland Emigration Act in the Central Provinces for the Year Ending 30 June, 1905.

${ }^{\infty}$ WBSA, Finance Emigration, December 1913, A1-3.

62 Extract from Capital, 9 February 1911. WBSA, General Emigration, January 1912, A1-32. 
Table 1. Number of cases of abduction by recruiters registered during 1911-1912

\begin{tabular}{llccc}
\hline Date & Region & $\begin{array}{c}\text { Total cases } \\
\text { against } \\
\text { recruiters }\end{array}$ & $\begin{array}{c}\text { "Abduction" } \\
\text { cases }\end{array}$ & $\begin{array}{c}\text { Percentage of } \\
\text { "abduction" cases } \\
\text { to total cases }\end{array}$ \\
\hline July-Sept. 1911 & Orissa & 4 & 2 & 50.00 \\
& Chota Nagpur & 34 & 20 & 58.82 \\
Oct.-Dec. 1911 & Orissa & 1 & 0 & 0 \\
& Chota Nagpur & 11 & 7 & 63.63 \\
& Bhagalpur & 3 & 1 & 33.33 \\
Jan.-March 1912 & Burdwan & 6 & 3 & 50.00 \\
April-June 1912 & Burdwan & 2 & 1 & 50.00 \\
\hline
\end{tabular}

Sources:

1 WBSA, General Emigration, June 1911, B7-24, File 5R-1.

2 lbid., December 1911, B4-19, File 5R-1.

3 lbid., February 1912, B43-58, File SR-1.

4 Ibid., May 1912, B48-57, File 5R-1.

5 Ibid., August 1912, B27-39, File SR-1.

indication of the extent of kidnapping of young women by recruiters. These figures can only be the tip of the iceberg, for it is likely that the majority of cases never found their way into courts and thence into government returns.

\section{The recruiters fight back}

However ineffective in achieving its avowed purpose, the Act made women's recruitment more difficult and expensive, especially for emigration agencies. They argued that between the need to maintain a steady number of women recruits and the provisions of Section 9, they were being squeezed from both ends. To entitle recruits to demand release from the depots after the recruiter had paid advances and transportation costs was to violate the spirit of the contract that underlay recruitment practices. Besides, the compensation they were paid was insufficient, especially in the case of women who were more expensive to recruit and were given more opportunity to revoke their contracts. ${ }^{62}$

A serious problem in applying the law on the ground came from another quarter. Section 9 was rendered relatively ineffective by the powerful lobbies interested in cheap female labour. A technical issue, the clause requiring a "lawful guardian" to register a complaint to the registering officer, became the ostensible ground of conflict between some local officials and the plantation and recruiting agencies. In 1903 J.N. Gupta, Magistrate of Bankura, suspected that a woman brought

2 L. Grommer, Emigration Agent for Surinam to the Protector of Emigrants, 24 April 1914. WBSA, Finance Emigration, November 1915, A22. 
before him for registration did not have the consent of her guardian. A long-drawn and expensive process lay before him. To cut the procedure short, he ordered that women needing to be registered would have to obtain a certificate from their local panchayat stating clearly that they wished "to enter labour contracts with the consent of their husbands or lawful guardians". ${ }^{63}$ Gupta's object was to "put a check to fraudulent recruitment by misrepresentation, coercion, undue influence". He argued that it was incumbent upon him "to prevent women from being cajoled away" especially since sections 34 and 69(2) of the Act had "laid much stress on the subject of making enquiry into all suspected cases of labour contract by women against the wishes or without the consent of her husband". ${ }^{4}$ The Tea Districts Labour Supply Association, however, thought otherwise. They held that such a directive would not only not fulfil its objective, it would "hamper recruiting operations" by giving "in the hands of village panchayats" a power that would be "utilised in placing additional difficulties in the way of sardari recruitment under the Act to what already exist". ${ }^{\text {.5 }}$ The government lent a sympathetic ear and O'Malley, the Secretary to the Government of Bengal, argued that "special enquiries should only be made when there is positive reason for suspecting that a woman, who is brought up for registration unaccompanied by her guardian, is being "cajoled away".66 The government directed the withdrawal of the order. Silence on the part of the guardian was to be construed as consent: "the presumption is that the guardian (if there is one) consents unless he comes forward to object". ${ }^{67}$

H. Savage, a registering magistrate for many years, to whom the Governor referred the case, pointed out that if preventing enticement was the purpose of the law, this ruling defeated it. Rather, he argued, "the panchayat's certificate is the lowest evidence that a Magistrate would be justified in accepting as evidence of the consent of husband or guardian in their absence". The presumption that "the guardian consents unless be comes forward to object is made on the further assumption that the guardian knows what has become of the woman, which, if there has been cajolery, is just what he would not know". ${ }^{68}$ This indeed was the hub of the matter. If silence was to be construed as consent, it was precisely cases of cajolery, enticement and fraudulent recruitments that would not be detected. ${ }^{69}$ A magistrate would not be able to act on his own initiative. Women who were deliberately escaping oppressive marriages, alone or with their lovers, found it relatively easy

WBSA, General Emigration, June 1903, A48-53.

Ibid.

os lbid.

Italies in original. Ibid., June 1904, A48-53.

67 Ibid.

os Italics in original. Ibid.

of Ibid., August 1904, A87-9. 
to conceal the facts from the registering magistrates. Married women thus recruited, if apprehended in time, could still be released from the depot on payment of Rs. 30. The amount itself would have been hard enough to find. Moreover, the fact of marriage had to be proved with three witnesses. If the woman was already at a depot in Ranchi, Naihati or Calcutta, proving the "factum of marriage" was extraordinarily difficult and many deserted husbands found themselves unable to pursue their charges.

In the case of widows, orphans and adopted girls, there was still a more fundamental question to settle. Who were their "lawful guardians"? What gave the tea lobby an edge against Gupta was that the particular case in which he gave the order for compulsory panchayati certification involved the recruitment of a young widow. Hence, in his memo O'Malley added the parenthesis: "the presumption is that the guardian (if there is one) consents unless he comes forward to object". ${ }^{70}$ It was often assumed that some widows, deserted and deserting wives were "single" women and if they were above the age of consent they were in fact competent to enter into labour contracts on their own behalf. The Emigration Report of 1912 thus categorized 69.45 per cent of migrants as "single women"." For some, especially elite Indian men, women's ability to take their own migration decisions constituted an illegitimate attack on the integrity of the family. They denounced the assumption that some women could be treated as "single" and therefore "free" to enter into labour contracts without permission from the male head of household. The Secretary of the Marwari Association, which had mounted a campaign against indentured labour, wrote to the Government of Bengal:

Women are decoyed as freely and with as much unconcern as men and registered as single, although women are never single in this country unless they happen to be widows. The object of registering them as such is evidently to show that they are free to act for themselves. But it is a well-known fact that women in this country are seldom free and are always under the guardianship of either their husbands or other relations. ${ }^{2}$

Even some registering officers who were faced with the everyday reality of rising abuses in recruitment of women were unimpressed by the specious arguments forwarded by the tea lobby and the recruiting agencies. The Deputy Commissioner of Ranchi felt that the real purpose of the 1901 Act was to ensure that "no woman was capable of binding herself by a labour contract if her husband or lawful guardian objects

r lbid.

$n$ Report on the Working of the Inland Emigration Act, (Calcutta, 1912).

$n$ Babu Ramdeo Chotham, Honorary Secretary, Marwari Association, to the Secretary to the Government of Bengal, 5 August 1915. WBSA, Finance Emigration, November 1915, B5-7. 
[...]" and that this obliged the registering officer to look carefully into the competency of a woman to execute a labour contract. He cited a case where a woman abducted by an unlicensed recruiter was paired off with another man and "to prevent any looking back on her part, got this newly formed couple to consummate their union in the jungle, where he first introduced them to each other". ${ }^{73}$

The recruiting agents, however, held fast to the technicality that under the Act the registering officer was not required to question sardari recruits, and had no power to enquire whether such women had the permission of their guardians. In a few cases where local officials took an initiative in cracking down on illegal recruitment, agents put up stiff resistance. ${ }^{74}$

In fact, most district officials were indifferent, if not actively in sympathy with recruiting agencies, many of which were owned and run by Europeans. Nanika's case received considerable publicity because it was taken up by a clergyman who had converted her to Christianity before her recruitment. ${ }^{75}$ The Reverend A. Logsdail complained that contrary to the Tea Association's vituperations, local officials took little action in cases of illegal recruitment. Nanika had been recruited by Mata Sardar and taken to a tea garden as his "wife". She had been registered under a false name and as a resident of Maurbhanj where she had never lived. When her mother complained to the police and applied to the District Officer for maintenance for herself and Nanika's young daughter the case was dismissed summarily

without any inquiry whatever from the complainant $[\ldots$ T] he Police took the depot folk's account without testing its soundness [ . . No ] women, or men either, [should] be taken off $[\ldots]$ without registration as so-called "free" coolies [...]. The petitioner asked for bread for herself and grandchild, she has been given a stone. ${ }^{76}$

Since the legislation had been undertaken primarily to reduce arkathi recruiting and promote "free" recruitment by sardars, some officials argued that enquiry into doubtful cases of recruitment by sardars would defeat the main purpose of the Act. Enquiries were not only inexpedient but unnecessary, since sardari recruitment was, by definition, "free" recruitment, and since the sardar recruited, with his limited resources, from his own locality within his known circle, such abuses were unlikely to occur. " Whatever the arguments advanced, that the Act was in

73 H.C. Streatfield, Deputy Commissioner of Ranchi, to the Commissioner of the Chota Nagpur Division, 23 September 1901. WBSA, General Emigration, December 1901, A.50-62.

${ }^{74}$ Emphasis in original. lbid., July 1913, B57-65.

"I Ibid., June 1905, A18-32.

76 The Statesman, 15 October 1904.

$\pi$ WBSA, General Emigration, December 1901, A50-62. 
practice ineffective was evident from the continued reports of illegal recruitment. Even as late as 1912 , the Magistrate of Gaya felt that the word "kidnapping" was being used frequently in connection with recruiters, both licensed and unlicensed, and that unless the most stringent checks were maintained there would be "instead of recruiters merely licensed kidnappers". ${ }^{78}$

\section{Conclusion}

The Sections 9, 34 and 69 had been included in the Act VI of 1901 to prevent women's fraudulent recruitment and to restrain women who sought to flee their families, voluntarily or because they had been deceived. These provisions were intended to propitiate patriarchal outrage. But the pressure from emigration agencies and various tea lobbies including the Indian Tea Planters' Association and the Tea Districts Labour Supply Association forced the government into various compromises. Registering magistrates were encouraged to wink at illegal recruitments which most of them did anyway. The Government of Bengal was more susceptible to the interests of recruiters than Delhi. By executive fiat, Calcutta neutralized the possibilities of rigorous enquiry into women's recruitment. It was precisely the kind of recruitment that the Act was meant to suppress that remained unchecked by the Government of Bengal's decision to hold by the rule that the husband/guardian would have to come forward before special enquiries could be made into a woman's recruitment. The controversy continued. From time to time, some district magistrates would attempt a more zealous application of the spirit of Section 9. The need to reconcile the interests of recruiters with familial claims over women's labour and sexuality remained an irritant until the practice of recruiting indentured labour was abolished.

73 T.S. MacPherson. Magistrate of Gaya to the Commissioner of the Patna Division. WBSA, General Emigration, March 1912, A9-12. 